Article

\title{
Simultaneous Electrochemical Generation of Ferrate and Oxygen Radicals to Blue BR Dye Degradation
}

\author{
Mauricio Chiliquinga ${ }^{1,2}$, Patricio J. Espinoza-Montero ${ }^{3, *} \mathbb{C}$, Oscar Rodríguez ${ }^{2}$, Alain Picos ${ }^{2}$, \\ Erick R. Bandala ${ }^{4}$ D , S. Gutiérrez-Granados ${ }^{2}$ and Juan M. Peralta-Hernández ${ }^{2, *(D)}$ \\ 1 Departamento de Ingeniería Civil y Ambiental, Facultad de Ingeniería Civil y Ambiental, Escuela Politécnica \\ Nacional. P.O. Box, Quito 17-01-2759, Ecuador; mauricioacade14@hotmail.com \\ 2 Departamento de Química, División de Ciencias Naturales y Exactas, Universidad de Guanajuato, \\ Cerro de la Venada s/n, Pueblito de Rocha, Guanajuato 36040, Mexico; \\ om.rodrigueznarvaez@ugto.mx (O.R.); picosbrother@hotmail.com (A.P.); gutigs59@hotmail.com (S.G.-G.) \\ 3 Escuela de Ciencias Químicas, Pontificia Universidad Católica del Ecuador, Avenida 12 de Octubre y Roca, \\ Apartado, Quito 17-01-2184, Ecuador \\ 4 Division of Hydrologic Sciences, Desert Research Institute, 755 E. Flamingo Road, \\ Las Vegas, NV 89119-7363, USA; Erick.Bandala@dri.edu \\ * Correspondence: pespinoza646@puce.edu.ec (P.J.E.-M.); juan.peralta@ugto.mx (J.M.P.-H.); \\ Tel.: +593-2299-1700 (ext. 1929) (P.J.E.-M.); +52-4737327555 (ext. 5416) (J.M.P.-H.)
}

Received: 10 March 2020; Accepted: 25 June 2020; Published: 28 June 2020

check for updates

\begin{abstract}
In this study, electro-oxidation (EOx) and in situ generation of ferrate ions [Fe(VI)] were tested to treat water contaminated with Blue BR dye (BBR) using a boron-doped diamond (BDD) anode. Two electrolytic media $\left(0.1 \mathrm{M} \mathrm{HClO}_{4}\right.$ and $\left.0.05 \mathrm{M} \mathrm{Na}_{2} \mathrm{SO}_{4}\right)$ were evaluated for the BDD, which simultaneously produced oxygen radicals $\left({ }^{\bullet} \mathrm{OH}\right)$ and $[\mathrm{Fe}(\mathrm{VI})]$. The generation of $[\mathrm{Fe}(\mathrm{VI})]$ was characterized by cyclic voltammetry $(\mathrm{CV})$ and the effect of different current intensity values (e.g., $7 \mathrm{~mA} \mathrm{~cm} \mathrm{~m}^{-2}, 15 \mathrm{~mA} \mathrm{~cm} \mathrm{~cm}^{-2}$, and $30 \mathrm{~mA} \mathrm{~cm}^{-2}$ ) was assessed during BBR degradation tests. The discoloration of BBR was followed by UV-Vis spectrophotometry. When the EOx process was used alone, only 78\% BBR discoloration was achieved. The best electrochemical discoloration conditions were found using $0.05 \mathrm{M} \mathrm{Na}_{2} \mathrm{SO}_{4}$ and $30 \mathrm{~mA} \mathrm{~cm}^{-2}$. Using these conditions, overall BBR discoloration values up to $98 \%, 95 \%$, and $87 \%$ with $12 \mathrm{mM}, 6 \mathrm{mM}$, and $1 \mathrm{mM}$ of $\mathrm{FeSO}_{4}$, respectively, were achieved. In the case of chemical oxygen demand (COD) reduction, the EOx process showed only a 37\% COD reduction, whereas combining [Fe(VI)] generation using $12 \mathrm{mM}$ of $\mathrm{FeSO}_{4}$ achieved an up to $61 \%$ COD reduction after $90 \mathrm{~min}$. The evolution of reaction byproducts (oxalic acid) was performed using liquid chromatography analysis.
\end{abstract}

Keywords: advace oxitadion processes (AOP); electro-oxidation; ferrate ion; BBR dye

\section{Introduction}

Industrial effluents contain a wide variety of pollutants that are potentially harmful to humans, such as dyes and organic compounds, and most of these pollutants are difficult to remove using conventional water treatment systems (e.g., physicochemical, and/or biological processes) [1]. When released into the environment without the proper treatment, these effluents produce significant fluctuations in water quality parameters such as chemical oxygen demand (COD), biological oxygen demand (BOD), pH, color, and/or salinity [2], which increase public concerns when the proper treatments are not being implemented. Therefore, finding alternative treatment processes that are suitable to remove highly recalcitrant pollutants in industrial wastewater effluents is a pending science and technology need. 
An alternative for water treatment known since the 1970 s has been ferrate(VI) ion $\left(\mathrm{FeO}_{4}{ }^{2-}\right)$, a very strong, chemically green oxidizer, highly stable in aqueous medium, especially at alkaline and neutral $\mathrm{pH}$, where iron shows oxidation state +6 [3-6]. However, we must emphasize that ferrate's highest oxidizing power occurs preferably in an acidic medium, and decreases in alkaline $\mathrm{pH}$ (reaction 1 and 2) $[4,7]$.

$$
\begin{array}{cc}
\mathrm{FeO}_{4}^{2-}+8 \mathrm{H}^{+}+3 \mathrm{e}^{-} \rightleftarrows \mathrm{Fe}^{3+}+4 \mathrm{H}_{2} \mathrm{O} & \mathrm{E}^{\circ}=+2.20 \mathrm{~V} \text { vs. SHE } \\
\mathrm{FeO}_{4}^{2-}+2 \mathrm{H}_{2} \mathrm{O}+3 \mathrm{e}^{-} \rightleftarrows \mathrm{Fe}(\mathrm{OH})_{3}+5 \mathrm{OH}^{-} & \mathrm{E}^{\circ}=+0.72 \mathrm{~V} \text { vs. SHE }
\end{array}
$$

Ferrate anions can exist in various oxidation states: $\left[\mathrm{FeO}_{4}\right]^{2-}$ with $\mathrm{Fe}(\mathrm{VI}),\left[\mathrm{FeO}_{4}\right]^{3-}$ with $\mathrm{Fe}(\mathrm{V})$ or $\left[\mathrm{FeO}_{4}\right]^{4-}$ with $\mathrm{Fe}(\mathrm{IV})$ [8]. However, $\mathrm{Fe}(\mathrm{VI})$ is the most stable form with broad industrial uses. The unique chemical properties of ferrate (VI) include:

(a) High redox potential, with the ability to oxidize harmful organic and inorganic species such as nitrosamines, phenol, nitrilotriacetic acid, hydrazine, thiourea, sulfides, cyanide, thioacetamide, ammonia, thiocyanate, soluble oils, as well as inactivate viruses and bacteria [5,8-11].

(b) A bifunctional ability to act as oxidizing and coagulating agent, due to the simultaneous release of ferric ions (Fe(III)), specifically under neutral or alkaline conditions [12-14].

(c) A higher redox potential than other oxidizers commonly used for water treatment such as chlorine (1.358 V vs. SHE), hydrogen peroxide (1.776 V vs. SHE), and ozone (2.076 V vs. SHE) [15].

(d) Ferrate use prevents the formation of carcinogenic disinfection byproducts (mainly trihalomethanes).

(e) It generates non-toxic reduction byproducts such as $\mathrm{Fe}(\mathrm{III})$ and $\mathrm{Fe}(\mathrm{II})$, which can be used for other purposes.

(f) Ferrate can also be used for biofouling control and for the removal of other contaminants such as metals, non-metals, and radionuclides [16-18].

Boron-doped diamond (BDD) electrodes have an inert surface, a wide electrochemical window, low adsorption, high corrosion resistance, and electrochemical stability. These electrodes are also considered a suitable surface upon which to carry out electro-oxidation (EOx) processes [19]. They have greater $\mathrm{O}_{2}$ evolution overpotential than other electrodes (e.g., $\mathrm{Pt}$ and $\mathrm{PbO}_{2}$ ) and low water oxidation reaction, combined with the capability to generate large amounts of oxygen radicals (e.g., $\left.{ }^{\bullet} \mathrm{OH}\right)$ [20]. Recent studies suggest that ferrate ions can be generated in situ from $\mathrm{Fe}(\mathrm{II})$ salts using a BDD anode surface under acidic conditions $\left(0.1 \mathrm{M} \mathrm{HClO}_{4}\right)$ by applying a potential of $2.2 \mathrm{~V}$ vs. NHE [21].

Despite the existing information about the potential of ferrate for water treatment [22-27] and the attractive features of its generation in situ by EOx processes, more research is needed to identify the best reaction conditions to treat complex industrial effluents using this technology. The goal of this work was to investigate the best conditions to generate ferrate ions in situ using a BDD electrode by cyclic voltammetry as well as assess the feasibility of using in situ generated ferrate simultaneously with the EOx process to degrade a textile dye (e.g., Blue BR (BBR) dye), following water discoloration, COD abatement, as well as an assessment of the evolution of reaction byproducts (e.g., carboxylic acids).

As is well known, the interest in studying the electrochemical generation of the ferrate ion on boron-doped diamond (BDD) electrodes, has gained great relevance; this due to its potential applications in the environmental area, specifically in water treatment. This paper presents results on the simultaneous production of the ferrate ion and free radicals on a BDD surface; studies of the generation of both species in two different electrolytes and with the addition of different concentrations of iron sulfate are presented, we also study the effect of the current density on the degradation of an industrial dye; for this, the level of discoloration, reduction in COD and the evolution of a byproduct, namely carboxylic acid, are considered. We consider this research to be relevant because we present important results on how the action of both oxidants generated on the same electrode simultaneously will improve the degradation of the dye, which enhances its application in water treatment. 


\section{Materials and Methods}

\subsection{Materials}

All reagents used in this investigation-perchloric acid $\left(\mathrm{HClO}_{4}\right)$, ferrous sulfate $\left(\mathrm{FeSO}_{4} \cdot 7 \mathrm{H}_{2} \mathrm{O}\right)$, sodium sulfate $\left(\mathrm{Na}_{2} \mathrm{SO}_{4}\right)$, and sulfuric acid $\left(\mathrm{H}_{2} \mathrm{SO}_{4}\right)$ - were obtained from Aldrich and J.T. Baker and used without any purification. The industrial grade $B B R$ dye $\left(\mathrm{C}_{32} \mathrm{H}_{28} \mathrm{~N}_{2} \mathrm{Na}_{2} \mathrm{O}_{8} \mathrm{~S}_{2}\right)$, widely used in the tanning industry in Mexico, was supplied by PCL (Guanajuato, Mexico). The BDD electrode was obtained from Metakem ${ }^{\mathrm{TM}}$ (Germany).

\subsection{Electrochemical Characterization}

The redox behavior of $\mathrm{FeSO}_{4}$ on BDD was evaluated by $\mathrm{CV}$, employing a three-electrode cell: BDD as an anode $\left(0.5 \mathrm{~cm}^{2}\right), \mathrm{Pt}$ wire as a counter electrode, and $\mathrm{Ag} / \mathrm{AgCl}$ as the reference electrode, using the BASi potentiostat/galvanostat and Epsilon-EC software at a scan rate ranging from $100 \mathrm{mV} \mathrm{s}^{-1}$ to $500 \mathrm{mV} \mathrm{s}^{-1}$. As an electrolyte (blank), we used $0.1 \mathrm{M} \mathrm{HClO}_{4}$ with $6 \mathrm{mM}$ of $\mathrm{FeSO}_{4}$ as analyte.

Additionally, the electrochemical response by cyclic voltammetry (CV) of three $\mathrm{FeSO}_{4}$ concentrations $(1 \mathrm{mM}, 6 \mathrm{mM}$, and $12 \mathrm{mM})$, in two different electrolytes $0.1 \mathrm{M} \mathrm{HClO}_{4}$ and $0.05 \mathrm{M} \mathrm{Na}_{2} \mathrm{SO}_{4}$ (adjusted to $\mathrm{pH} 3$ with $\mathrm{H}_{2} \mathrm{SO}_{4}$ ) was evaluated. The experiments were performed in a three-electrode electrochemical cell $(25 \mathrm{~mL})$, using a BDD $\left(0.5 \mathrm{~cm}^{2}\right)$ plate as a working electrode, platinum (Pt) wire as a counter electrode, and $\mathrm{Ag} / \mathrm{AgCl}$ as a reference electrode. The $\mathrm{CV}$ tests were performed using a $\mathrm{BASi}$ Epsilon potentiostat/galvanostat. Specific concentrations of $\mathrm{FeSO}_{4}$ were prepared from a stock solution in $100 \mathrm{~mL}$ of distilled water and added to the media in all the $[\mathrm{Fe}(\mathrm{VI})]$ production experiments.

\subsection{Electrochemical Set Up}

The discoloration assays were carried out in galvanostatic mode using three different current density values (e.g., $7 \mathrm{~mA} \mathrm{~cm}{ }^{2}, 15 \mathrm{~mA} \mathrm{~cm}^{2}$, and $30 \mathrm{~mA} \mathrm{~cm}^{2}$ ) in a $100 \mathrm{~mL}$ tank reactor with constant magnetic stirring $(200 \mathrm{rpm})$. One initial BBR dye concentration $(50 \mathrm{mg} / \mathrm{L})$ was used for all the experimental trials. The BBR dye (chemical formula $=\mathrm{C}_{32} \mathrm{H}_{28} \mathrm{~N}_{2} \mathrm{Na}_{2} \mathrm{O}_{8} \mathrm{~S}_{2}$, molecular weight = $678.68 \mathrm{~g} / \mathrm{mol}$, and $\lambda_{\max }=695 \mathrm{~nm}$ ) was used in this study. An accurately weighed quantity of the dye was dissolved in distilled water to prepare the stock solution $\left(100 \mathrm{mg} \mathrm{L}^{-1}\right)$. Experimental solutions of desired concentration $(50 \mathrm{mg} / \mathrm{L})$ were obtained by successive dilution. The surface area of the BDD anode was $2.5 \mathrm{~cm}^{2}$ and a Pt wire was used as the cathode. The study solution was monitored for color reduction using a UV-Vis spectrophotometer (Cintra 1010 device) at $\lambda=695 \mathrm{~nm}$ [27].

Water discoloration was carried out by testing two electrolytic media: $0.1 \mathrm{M} \mathrm{HClO}_{4}$ and $0.05 \mathrm{M}$ $\mathrm{Na}_{2} \mathrm{SO}_{4}$ adjusted to $\mathrm{pH} 3$ with $\mathrm{H}_{2} \mathrm{SO}_{4}$. In both cases, three different $\mathrm{FeSO}_{4}$ concentrations $(1 \mathrm{mM}$, $6 \mathrm{mM}$, and $12 \mathrm{mM}$ ) were tested. To evaluate the amount of remaining oxidable material in solution, the chemical oxygen demand (COD) was quantified according to the Standard Methods (method 5220D); total nitrogen concentration was also estimated by the Standard Methods [28].

For the different parameters tested, the kinetics approach of the combined electrochemical degradation of $B B R$ dye was determined by a pseudo-first order model, $\operatorname{Ln}\left(A_{0} / A_{t}\right)=k t$, where $A_{0}$ is the initial absorbance, $A_{t}$ is the absorbance after degradation time $t$, and $k$ is the apparent rate constant.

Carboxylic acids were identified and quantified by ion-exclusion HPLC using an Agilent Technologies 1260 Infinity Series with a Bio-Rad Aminex HPX $87 \mathrm{H}(300 \mathrm{~mm} \times 7.8 \mathrm{~mm}$ ) column at $35{ }^{\circ} \mathrm{C}$ and by setting the photodiode detector at $\lambda=210 \mathrm{~nm}$. For these determinations, $20 \mu \mathrm{L}$ of the sample was injected into the HPLC, using $4 \mathrm{mM}$ of $\mathrm{H}_{2} \mathrm{SO}_{4}$ as the mobile phase and flow rate $0.8 \mathrm{~mL} / \mathrm{min}$ [29-32]. The quantification of the COD was carried out only for the best BBR degradation conditions (e.g., electrolytic solution of $0.05 \mathrm{M}_{\text {of }} \mathrm{Na}_{2} \mathrm{SO}_{4}$ at a $\mathrm{pH}$ of 3, current density of $30 \mathrm{~mA} \mathrm{~cm}^{-2}$, and $12 \mathrm{mM}$ of $\mathrm{FeSO}_{4}$ ) following the Standard Methods [29]. 


\section{Results and Discussion}

\subsection{Cyclic Voltammetric (CV) Study}

Figure 1 shows the redox behavior of $6 \mathrm{mM}$ of $\mathrm{FeSO}_{4}$ on BDD at different scan rates $\left(100 \mathrm{mV} \mathrm{s}^{-1}\right.$ to $500 \mathrm{mV} \mathrm{s}^{-1}$ ) using $0.1 \mathrm{M} \mathrm{HClO}_{4}$ as electrolyte. It is worth emphasizing that the linear behavior of the second peaks agree with the Randles-Sevcik equation ( $I_{p}$ vs. (scan rate) ${ }^{1 / 2}$ ) (data not shown), indicating a diffusion-controlled process where the redox species are not adsorbed on the surface of the electrode [33]. In this study, oxidation peaks from $\mathrm{Fe}(\mathrm{II})$ to $\mathrm{Fe}(\mathrm{III})$ were observed at $0.54 \mathrm{~V}$ vs. $\mathrm{Ag} / \mathrm{AgCl}$, the overoxidation of $\mathrm{Fe}(\mathrm{III})$ to $[\mathrm{Fe}(\mathrm{VI})]$ was found at $0.90 \mathrm{~V}$ vs. $\mathrm{Ag} / \mathrm{AgCl}$, and reduction to $\mathrm{Fe}(\mathrm{II})$ was identified at $0.25 \mathrm{~V}$ vs. $\mathrm{Ag} / \mathrm{AgCl}$. These results support the theory of in situ formation of [Fe(VI)] on the BDD surface, as shown in Figure 1 [34]. In Figure 2 the electrogeneration of the ferrate ion can be confirmed as the concentration of $\mathrm{FeSO}_{4}$ increases both the oxidation signal from $\mathrm{Fe}$ (II) to $\mathrm{Fe}$ (III) and the oxidation signal from $\mathrm{Fe}(\mathrm{III})$ to $[\mathrm{Fe}(\mathrm{VI})]$ increases proportionally. The number of oxidation and reduction signals matches with those described for Figure 1, even though a slight displacement in the potential axis was observed, probably related to the amount of $\mathrm{FeSO}_{4}$ used for the media. However, ferrate ion production was found to increase as the concentration of $\mathrm{FeSO}_{4}$ increased [35]. In a previous work, our research group suggested ferrate ion formation at potential values close to $2.5 \mathrm{~V} \mathrm{Ag} / \mathrm{AgCl}$, using $0.1 \mathrm{M} \mathrm{HClO}_{4}[21,35]$. The difference in the oxidation and over-oxidation reaction behavior of $\mathrm{Fe}(\mathrm{II})$ to $\mathrm{Fe}(\mathrm{III})$ and $\mathrm{Fe}(\mathrm{VI})$, respectively, observed in this study could be related to the composition of the electrode surface (C-sp $/ \mathrm{C}$-sp $\mathrm{sp}^{3}$ ratio), usage time, and the composition of BDD during its syntheses (e.g., doping level, or precursor used) [36].

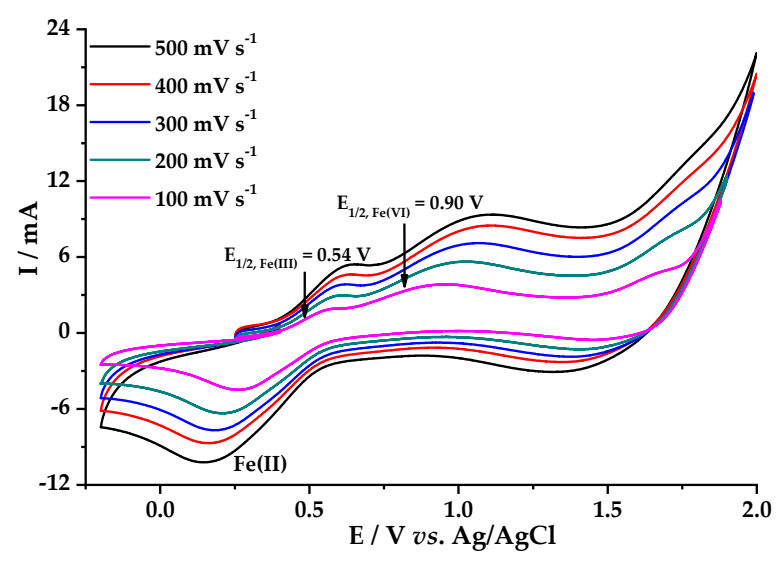

Figure 1. Behavior of $6 \mathrm{mM} \mathrm{FeSO}_{4}$ at different voltammetric scan rate, in $0.1 \mathrm{M} \mathrm{HClO}_{4}$, on 0.5 borondoped diamond (BDD) $\mathrm{cm}^{2}$ as working electrode; counter electrode-platinum wire.

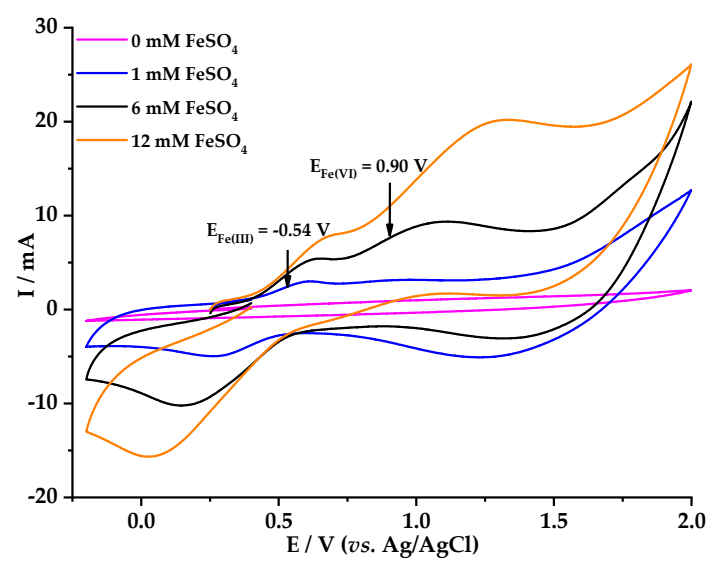

Figure 2. Voltammetric response of $\mathrm{FeSO}_{4}$ at different concentrations in $0.1 \mathrm{M} \mathrm{HClO}_{4}$, with BDD $0.5 \mathrm{~cm}^{2}$ as working electrode, scanning speed $50 \mathrm{mV} \mathrm{s}^{-1}$; counter electrode-platinum wire. 
Figure 3 shows the redox behavior of $6 \mathrm{mM} \mathrm{FeSO}_{4}$ on BDD, at different scan rates $\left(50 \mathrm{mV} \mathrm{s}^{-1}\right.$ to $100 \mathrm{mV} \mathrm{s}^{-1}$ ) using $0.05 \mathrm{M} \mathrm{Na}_{2} \mathrm{SO}_{4}$ as electrolyte after adjusting $\mathrm{pH}$ to 3 with concentrated $\mathrm{H}_{2} \mathrm{SO}_{4}$. Two signals for oxidation from $\mathrm{Fe}(\mathrm{II})$ to $\mathrm{Fe}(\mathrm{III})$ at $-0.30 \mathrm{~V}$ vs. $\mathrm{Ag} / \mathrm{AgCl}$ were identified, plus another for overoxidation of $\mathrm{Fe}(\mathrm{II})$ to $\mathrm{Fe}(\mathrm{VI})$ at $0.78 \mathrm{~V}$ vs. $\mathrm{Ag} / \mathrm{AgCl}$. Figure 4 shows the effect of $\mathrm{FeSO}_{4}$ concentration when a constant scan rate $\left(50 \mathrm{mV} \mathrm{s}^{-1}\right)$ was used. It is worth noting that at increased concentrations of $\mathrm{FeSO}_{4}$, the oxidation and reduction signals increase slightly and move significantly towards higher values of both oxidation and reduction potential. In addition, the second oxidation signal appeared at a lower potential value when $\mathrm{Na}_{2} \mathrm{SO}_{4}$ was used as the electrolyte $(0.78 \mathrm{~V}$, Figure 4$)$, compared with the signal obtained when $\mathrm{HClO}_{4}$ was used as the electrolyte $(0.90 \mathrm{~V}$, Figure 2). Therefore, better degradation of BBR would be expected when $\mathrm{Na}_{2} \mathrm{SO}_{4}$ is used as the electrolyte, as this reaction media would favor the formation of ferrate ion at lower potential values [37].

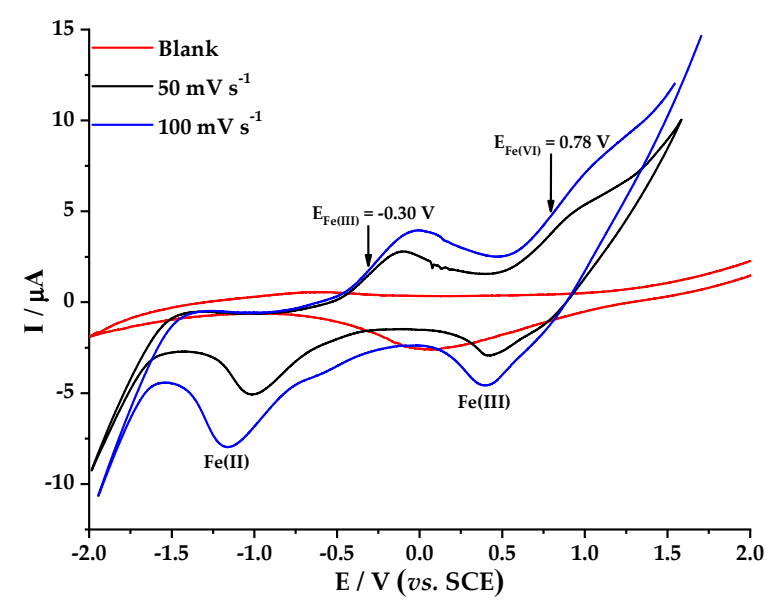

Figure 3. Behavior of $6 \mathrm{mM} \mathrm{FeSO}_{4}$ at different voltammetric scan rate, $0.05 \mathrm{M} \mathrm{Na}_{2} \mathrm{SO}_{4}$, on BDD $0.5 \mathrm{~cm}^{2}$ as working electrode; counter electrode-platinum wire.

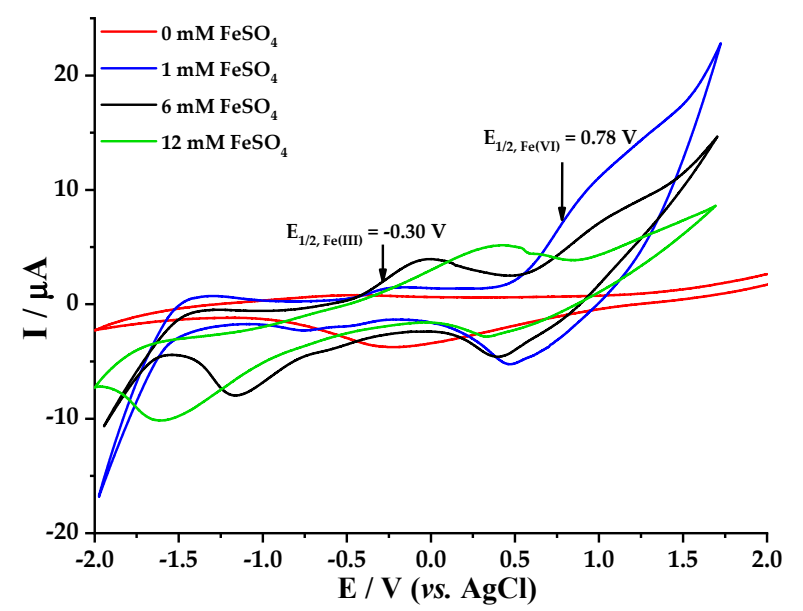

Figure 4. Voltammetric response of $\mathrm{FeSO}_{4}$ at different concentrations, $0.05 \mathrm{M} \mathrm{Na}_{2} \mathrm{SO}_{4}$, on $\mathrm{BDD} 0.5 \mathrm{~cm}^{2}$ as working electrode, scan rate $50 \mathrm{mV} \mathrm{s}^{-1}$; counter electrode-platinum wire.

\subsection{BBR Dye Degradation}

\subsubsection{Effect of the Electrolyte on the EOx Discoloration Process}

The effect of the electrolyte type on the EOx discoloration was explored first. Figure 5 shows the discoloration curves as a function of reaction time for $\mathrm{HClO}_{4}$ (Figure 5a) and $\mathrm{Na}_{2} \mathrm{SO}_{4}$ (Figure 5b) at the different current density values tested (e.g., $7 \mathrm{~mA} \mathrm{~cm}^{-2}, 15 \mathrm{~mA} \mathrm{~cm}{ }^{-2}$, and $30 \mathrm{~mA} \mathrm{~cm}{ }^{-2}$ ). As shown, no significant difference was found when the lower current density $\left(7 \mathrm{~mA} \mathrm{~cm}^{-2}\right)$ was tested 
independently of the electrolyte type used. Nevertheless, a significant difference was found when higher current density values were tested. For example, an overall discoloration of $23 \%$ was achieved using $15 \mathrm{~mA} \mathrm{~cm}^{-2}$ and $0.1 \mathrm{M} \mathrm{HClO}_{4}$, whereas up to $62 \%$ of overall discoloration (over twice the amount achieved reached for $\mathrm{HClO}_{4}$ ) was achieved when $0.05 \mathrm{M} \mathrm{Na}_{2} \mathrm{SO}_{4}$ was used as the electrolyte.
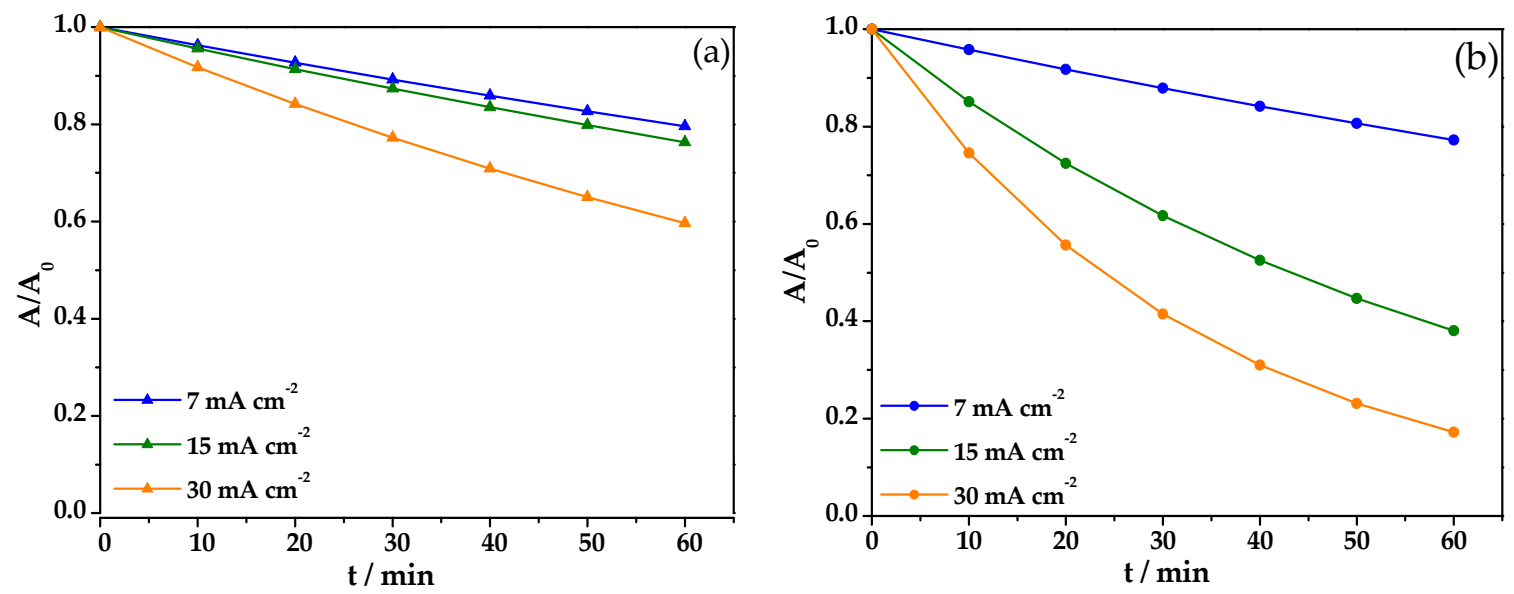

Figure 5. Removal of an aqueous solution of Blue BR (BBR) azo dye, $\mathrm{C}_{0}=50 \mathrm{mg} / \mathrm{L}$, during the oxidation

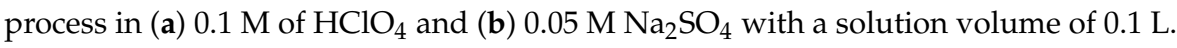

When the highest current density $\left(30 \mathrm{~mA} \mathrm{~cm}{ }^{-2}\right)$ was tested, the overall water discoloration achieved after $60 \mathrm{~min}$ was $49 \%$ for $0.1 \mathrm{M} \mathrm{HClO}_{4}$, whereas the trials using $0.05 \mathrm{M} \mathrm{Na}_{2} \mathrm{SO}_{4}$ showed an overall water discoloration as high as $82 \%$. It is worth noting that $\mathrm{HClO}_{4}$ consistently produced lower overall discoloration than $\mathrm{Na}_{2} \mathrm{SO}_{4}$ under the same experimental conditions. These results could be due to halide electrolytes generating active halide species, which has been suggested in other studies [38]. In their report, Ambauen et al. [38] found that once hydroxyl radicals are formed, secondary reactions may occur when electrochemically active electrolytes are present, including the scavenging of the reactive oxygen species and the secondary production of other less reactive species that are capable of reacting with the organic pollutants under some conditions, resulting in partial chemical oxidation. However, based on the mechanisms for active chloride-mediated electrochemical oxidation, this type of side reaction is not favored because, in most cases, chlorinated byproducts possess a higher toxicity.

On the other hand, using $\mathrm{Na}_{2} \mathrm{SO}_{4}$ in the EOx-based discoloration of dye water has interesting potential. Previously, we used a BDD anode to remove different industrial sulfonated dye products from water [39]. In that study, we found BBR discoloration ranging from $25 \%$ to $95 \%$, which was possibly related to the production of a low and steady concentration of oxygen radical on the BDD surface attacking the dye molecules. The best results were achieved using the highest current density value tested (e.g., $18 \mathrm{~mA} \mathrm{~cm}^{-2}$ ), a pH of 3, a $0.5 \mathrm{~L}$ laboratory stirred tank reactor, and a $25 \mathrm{~cm}^{2} \mathrm{BDD}$ electrode. In this study, we achieved up to $82 \%$ of BBR discoloration for the same reaction time reported previously, but using a BDD electrode area one order of magnitude lower (e.g., $\left.2.5 \mathrm{~cm}^{2}\right)$.

From this study, pseudo-first-order kinetics were calculated as described above. In the case of $\mathrm{HClO}_{4}$ medium, the following results were obtained: ( $\left.\Delta\right) 0.0038,(\Delta) 0.0045,(\Delta) 0.0086 \mathrm{~min}^{-1}$, respectively. For the $\mathrm{Na}_{2} \mathrm{SO}_{4}$ supporting electrolyte, the following values were obtained: $(\diamond) 0.0043,(\diamond)$ $0.0161,(\diamond) 0.0293 \mathrm{~min}^{-1}$, respectively. For all the experimental fittings using the pseudo-first order kinetics model, the minimum $\mathrm{R}^{2}$ value obtained was 0.99 , suggesting that this kinetics model describes the chemical process fairly good. As shown, the $k$-values found for $\mathrm{Na}_{2} \mathrm{SO}_{4}$ were about 3.5 times higher than those observed when $\mathrm{HClO}_{4}$ was used as the supporting electrolyte. 


\subsubsection{BBR Dye Degradation at Different Current Densities in $0.1 \mathrm{M} \mathrm{HClO}_{4}$ and $\mathrm{FeSO}_{4}$}

Figure 6a shows water discoloration as a function of $\mathrm{FeSO}_{4}$ concentration using a current density of $7 \mathrm{~mA} \mathrm{~cm}^{-2}$. Slow discoloration was observed for the EOx process alone ( $\bullet$ ), and $31 \%$ BBR degradation and $k$-value $0.0030 \mathrm{~min}^{-1}$ were achieved. By adding $1 \mathrm{mM}$ of $\mathrm{FeSO}_{4}$ to the system $(\mathbf{\Lambda})$, a $38 \%$ discoloration and $k$-value $0.0035 \mathrm{~min}^{-1}$ were achieved. Further increasing the $\mathrm{FeSO}_{4}$ concentration (e.g., $6 \mathrm{mM}(\boldsymbol{\bullet})$, and $12 \mathrm{mM}(\bullet))$ led to water discoloration values of $41 \%$ and $46 \%$, respectively, and reaction rate constant values of $0.0038 \mathrm{~min}^{-1}$ and $0.0042 \mathrm{~min}^{-1}$, respectively, were obtained after two hours of treatment $[40,41]$.
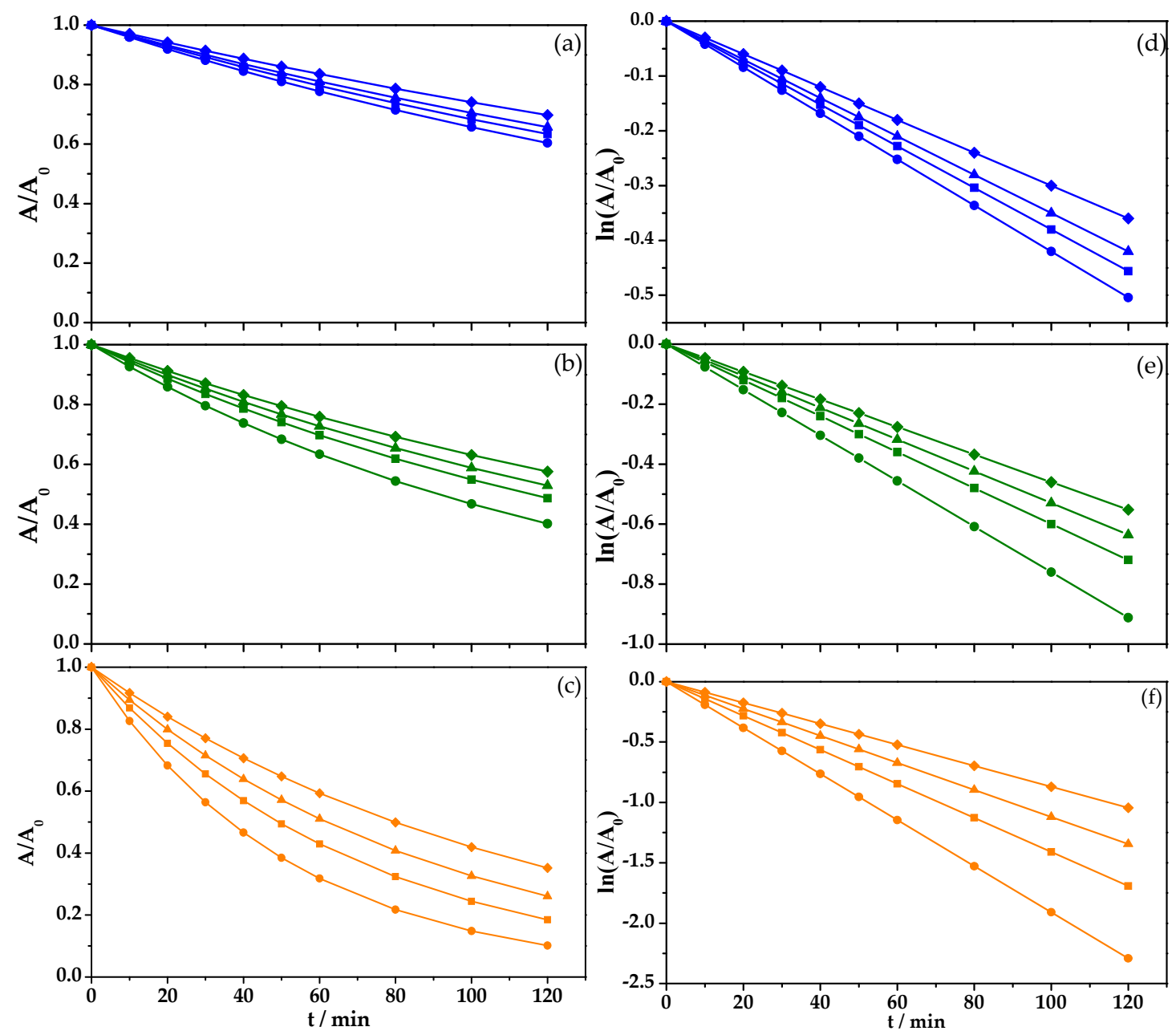

Figure 6. Removal of an aqueous solution of $\mathrm{BBR}$ azo dye, $\mathrm{C}_{0}=50 \mathrm{mg} / \mathrm{L}$, during the oxidation process in $0.1 \mathrm{M}$ of $\mathrm{HClO}_{4}$ with a solution volume of $0.1 \mathrm{~L},(\mathbf{a}) \mathrm{j}=7 \mathrm{~mA} \mathrm{~cm}{ }^{-2},(\mathbf{b}) \mathrm{j}=15 \mathrm{~mA} \mathrm{~cm}{ }^{-2},(\mathbf{c}) \mathrm{j}=$ $30 \mathrm{~mA} \mathrm{~cm}^{-2}$, and fit to first order reaction kinetics (d), (e) y (f), respectively; ( $)$ BDD without $\mathrm{FeSO}_{4}$, (ム) $1 \mathrm{mM}$ of $\mathrm{FeSO}_{4},(\boldsymbol{\square}) 6 \mathrm{mM}$ of $\mathrm{FeSO}_{4}$, and $(\bullet) 12 \mathrm{mM}$ of $\mathrm{FeSO}_{4}$.

When current density was increased to $15 \mathrm{~mA} \mathrm{~cm}^{-2}$ (Figure 6b), an improvement in discoloration tendency was observed, and the increase in $\mathrm{FeSO}_{4}$ concentration produced a higher removal speed and discoloration percentage. For the EOx process alone ( $\bullet$ ), a $46 \%$ discoloration and $k_{1}$-value of $0.0046 \mathrm{~min}^{-1}$ were observed. When $1 \mathrm{mM}^{-1} \mathrm{FeSO}_{4}(\mathbf{\Lambda})$ was used, a $50 \%$ discoloration and $k_{1}$-value of $0.0053 \mathrm{~min}^{-1}$ were achieved. Using $6 \mathrm{mM}$ of $\mathrm{FeSO}_{4}(\mathbf{-})$ produced a $54 \%$ discoloration and $k_{1}$-value of $0.0060 \mathrm{~min}^{-1}$. Finally, the process with the greatest discoloration used $12 \mathrm{mM}$ of $\mathrm{FeSO}_{4}(\bullet)$, generating a $63 \%$ discoloration after two hours of treatment and a $k_{1}$-value of $0.0076 \mathrm{~min}^{-1}$.

Further increasing the current density to $30 \mathrm{~mA} \mathrm{~cm}^{-2}$ showed the best results, as shown in Figure $6 \mathrm{c}$. Compared with the other conditions tested, the highest discoloration was achieved by 
adding $12 \mathrm{mM}_{\text {of }} \mathrm{FeSO}_{4}(\bullet)$ into the solution, followed by adding $6 \mathrm{mM}$ of $\mathrm{FeSO}_{4}(\mathbf{\bullet}), 1 \mathrm{mM}$ of $\mathrm{FeSO}_{4}$ $(\mathbf{\Lambda})$, and finally using the EOx process alone $(\boldsymbol{\nabla})$, which produced water discoloration values as high as $93 \%, 85 \%, 77 \%$, and $67 \%$, respectively, and $k_{1}$-values of $0.0191 \mathrm{~min}^{-1}, 0.0141 \mathrm{~min}^{-1}, 0.0112 \mathrm{~min}^{-1}$, and $0.0087 \mathrm{~min}^{-1}$, respectively.

\subsubsection{BBR Dye Degradation at Different Current Densities in $0.05 \mathrm{M}$ of $\mathrm{Na}_{2} \mathrm{SO}_{4}$ and $\mathrm{FeSO}_{4}$}

Figure $7 \mathrm{a}$ shows the degradation of BBR dye $\left(50 \mathrm{mg} \mathrm{L}^{-1}\right)$ using $0.05 \mathrm{M} \mathrm{Na}_{2} \mathrm{SO}_{4}$ at $\mathrm{pH} 3$ as the support electrolyte after $60 \mathrm{~min}$. It is worth noting that continuous dye degradation was observed for the four different conditions tested: EOx alone and adding $1 \mathrm{mM}, 6 \mathrm{mM}$, and $12 \mathrm{mM}$ of $\mathrm{FeSO}_{4}$ while operating at a constant current density $\left(7 \mathrm{~mA} \mathrm{~cm}^{-2}\right)$. The EOx process alone $(\downarrow)$ showed $36 \%$

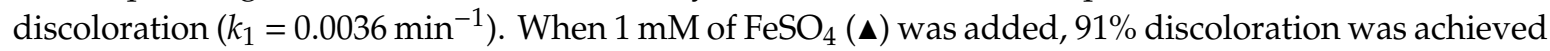
$\left(k_{1}=0.0052 \mathrm{~min}^{-1}\right)$.
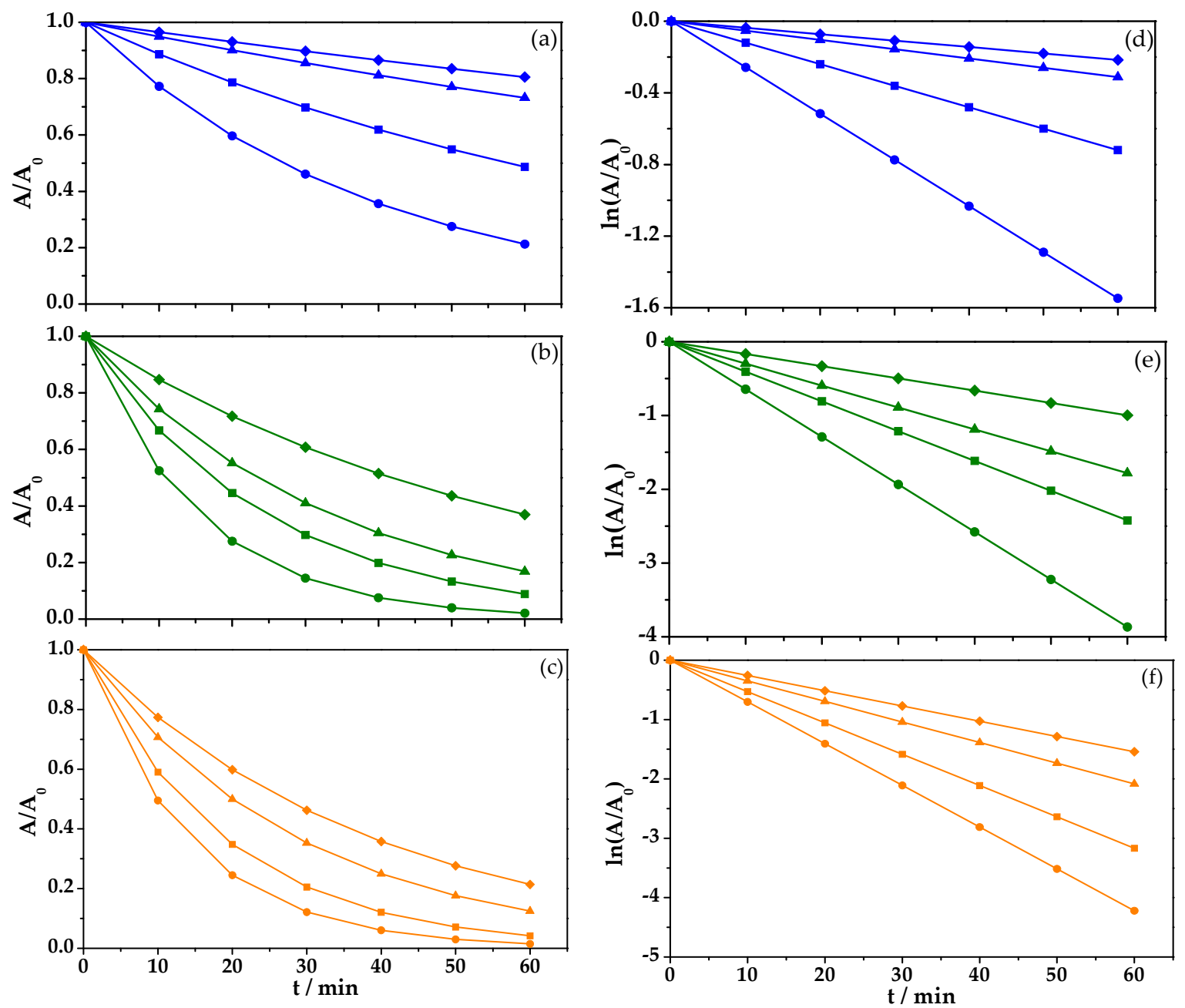

Figure 7. Removal of an aqueous solution of BBR azo dye, $\mathrm{C}_{0}=50 \mathrm{mg} / \mathrm{L}$, during the oxidation process in $0.05 \mathrm{M}$ of $\mathrm{Na}_{2} \mathrm{SO}_{4}$ and at a $\mathrm{pH}$ of 3 with a solution volume of $0.1 \mathrm{~L},(\mathbf{a}) \mathrm{j}=7 \mathrm{~mA} \mathrm{~cm}{ }^{-2},(\mathbf{b}) \mathrm{j}=$ $15 \mathrm{~mA} \mathrm{~cm}^{-2}$, (c) j $=30 \mathrm{~mA} \mathrm{~cm}^{-2}$, and fit to first order reaction kinetics (d), (e) y (f), respectively; ( $)$ BDD without $\mathrm{FeSO}_{4},(\boldsymbol{\Delta}) 1 \mathrm{mM}$ of $\mathrm{FeSO}_{4},(\boldsymbol{\bullet}) 6 \mathrm{mM}$ of $\mathrm{FeSO}_{4}$, and $(\bullet) 12 \mathrm{mM}$ of $\mathrm{FeSO}_{4}$.

Water discoloration as high as $94 \%$ was observed when $6 \mathrm{mM}$ of $\mathrm{FeSO}_{4}$ was added $(\mathbf{\square})\left(k_{1}=\right.$ $0.0120 \mathrm{~min}^{-1}$ ), and finally the faster discoloration (e.g., $96 \%, k_{1}=0.0258 \mathrm{~min}^{-1}$ ) was achieved after 60 min of treatment using $12 \mathrm{mM}$ of $\mathrm{FeSO}_{4}(\bullet)$.

Increasing the current density to $15 \mathrm{~mA} \mathrm{~cm}^{-2}$ (Figure $7 \mathrm{~b}$ ) generated better results for BBR dye discoloration for shorter process times. When EOx was used alone $(\bullet), 63 \%\left(k_{1}=0.0166 \mathrm{~min}^{-1}\right)$ was 


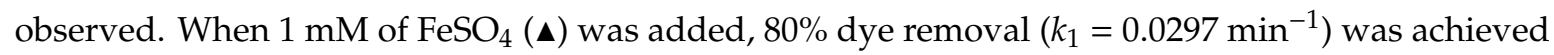
after $60 \mathrm{~min}$. By increasing $\mathrm{FeSO}_{4}$ to $6 \mathrm{mM}(\boldsymbol{\bullet}), 89 \%\left(k_{1}=0.0404 \mathrm{~min}^{-1}\right)$ was reached and, when using $12 \mathrm{mM}$ of $\mathrm{FeSO}_{4}(\bullet), 96 \%\left(k_{1}=0.0645 \mathrm{~min}^{-1}\right)$ was reached after $60 \mathrm{~min}$.

The same tendency was observed when the highest current density $\left(30 \mathrm{~mA} \mathrm{~cm}{ }^{-2}\right)$ was applied, as shown in Figure 7c. In this case, using $12 \mathrm{mM}$ of $\mathrm{FeSO}_{4}(\bullet)$ generated 98\% discoloration $\left(k_{1}=\right.$ $\left.0.0703 \mathrm{~min}^{-1}\right)$, and using $6 \mathrm{mM}$ of $\mathrm{FeSO}_{4}(\mathbf{\square})$ generated $95 \%$ discoloration $\left(k_{1}=0.0528 \mathrm{~min}^{-1}\right)$. Using $1 \mathrm{mM}$ of $\mathrm{FeSO}_{4}(\mathbf{\Lambda}), 87 \%$ discoloration $\left(k_{1}=0.0347 \mathrm{~min}^{-1}\right)$ was achieved, and finally EOx alone ( $)$ only reached $78 \%$ discoloration $\left(k_{1}=0.0257 \mathrm{~min}^{-1}\right)$ after $60 \mathrm{~min}$.

Based on these results, a combined BBR oxidation process is proposed. For the first case where we used $\mathrm{FeSO}_{4}$ and $\mathrm{HClO}_{4}$ as an electrolyte, the oxidation process would occur directly on the BDD electrode (EOx) and indirectly (chemically) through the hydroxyl radicals (resulting from water oxidation) and ferrate ions (resulting from $\mathrm{FeSO}_{4}$ oxidation), as in Scheme 1, reactions 4, 5 and 8. For the second case, where $\mathrm{FeSO}_{4}$ and $\mathrm{Na}_{2} \mathrm{SO}_{4}$ were used as electrolyte, the BBR oxidation process occurs directly on the BDD electrode (EOx, reaction 5) and indirectly (chemically) through the hydroxyl radicals (resulting from water oxidation, reactions 3 and 4), ferrate (VI) ions (resulting from $\mathrm{FeSO}_{4}$ oxidation, reactions 7 and 8) and perosodisulfates (resulting from the oxidation of $\mathrm{Na}_{2} \mathrm{SO}_{4}$, reactions 9 and 10), as in the Scheme 2 [42]. The formation of peroxodisulfate causes the latter case to be more effective in the oxidation of the BBR.

Based on the above, the simultaneous processes of EOx and the generation of ferrate ions in situ can be summarized with the following reactions [21]:

1. Discharge of water into the system and generation of oxygen radicals $\left(\bullet^{\bullet} \mathrm{OH}\right)$.

$$
\mathrm{BDD}+\mathrm{H}_{2} \mathrm{O} \rightarrow \mathrm{BDD}(\bullet \mathrm{OH})+\mathrm{H}^{+}+\mathrm{e}^{-}
$$

2. Oxidation of contaminants by oxygen radicals $(\bullet \mathrm{OH})$.

$$
\mathrm{BDD}(\bullet \mathrm{OH})+\mathrm{R} \rightarrow \mathrm{BDD}+\mathrm{nCO}_{2}+\mathrm{mH}_{2} \mathrm{O}
$$

3. Oxidation of contaminants on BDD.

$$
\operatorname{BDDpolarized}(+)+\mathrm{R} \rightarrow \mathrm{BDD}\left(\mathrm{nCO}_{2}\right)+\mathrm{mH}_{2} \mathrm{O}
$$

4. Generation of $[\mathrm{Fe}(\mathrm{VI})]$ from $\mathrm{FeSO}_{4}$ on BDD.

$$
\begin{gathered}
\text { oxidation : } \mathrm{Fe}^{2+}+\cdot \mathrm{OH} \rightleftarrows \mathrm{Fe}^{3+}+\mathrm{OH}^{-} \\
\text {over - oxidation : } \mathrm{Fe}^{3+}+4 \mathrm{H}_{2} \mathrm{O} \rightleftarrows \mathrm{FeO}_{4}^{2-}+8 \mathrm{H}^{+}+3 \mathrm{e}^{-}
\end{gathered}
$$

5. Oxidation of organic compounds by $[\mathrm{Fe}(\mathrm{VI})]$ and $\mathrm{S}_{2} \mathrm{O}_{8}^{2-}$ :

$$
\begin{gathered}
{[\mathrm{Fe}(\mathrm{VI})]+\mathrm{R} \rightarrow \mathrm{Fe}(\mathrm{III})+\mathrm{IS}+\mathrm{nCO}_{2}+\mathrm{mH}_{2} \mathrm{O}} \\
2 \mathrm{SO}_{4}^{2-} \rightarrow \mathrm{S}_{2} \mathrm{O}_{8}^{2-}+2 \mathrm{e}^{-} \\
\left.\mathrm{S}_{2} \mathrm{O}_{8}^{2-}+\mathrm{R} \rightarrow 2 \mathrm{SO}_{4}^{2-}+\mathrm{IS}+\mathrm{nCO}_{2}+\mathrm{mH}_{2} \mathrm{O}\right)
\end{gathered}
$$

For this study, stages (e) and (f) were avoided by working at low $\mathrm{FeSO}_{4}$ concentrations, which promoted a synergistic effect in stages (b) and (d). 


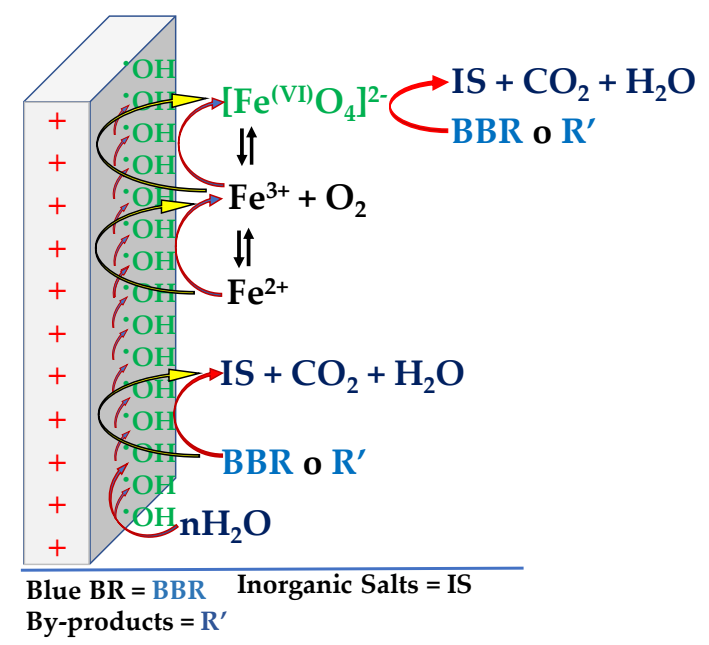

Scheme 1. Representation of the reactions involved on BDD substrate electrode held in $\mathrm{FeSO}_{4}$ and $0.1 \mathrm{M}$ of $\mathrm{HClO}_{4}$.

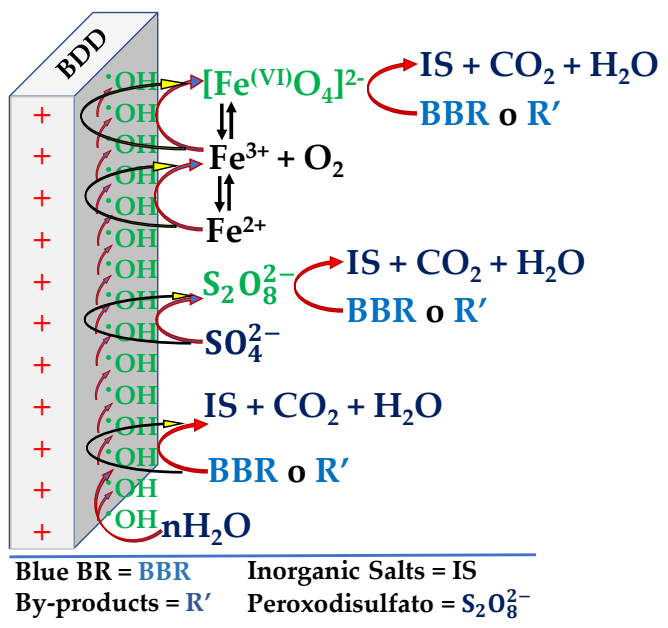

Scheme 2. Representation of the reactions involved on BDD substrate electrode held in $\mathrm{FeSO}_{4}$ and $0.05 \mathrm{M} \mathrm{Na}_{2} \mathrm{SO}_{4}$.

\subsubsection{COD Determinations and Byproduct Evolution}

In Figure 8, COD reduction is shown by comparing EOx alone ( $\downarrow)$ with the in situ generation of $[\mathrm{Fe}(\mathrm{VI})](\bullet)$. Electro-oxidation alone was able to achieve 37\% COD removal after $90 \mathrm{~min}$ of treatment. In the case of ferrate generation, $61 \%$ COD removal was obtained, suggesting electrogenerated [Fe(VI)] ions directly influence a decrease in COD by carrying out pollutant degradation more efficiently and reducing the amount of oxidable matter in the solution [43,44].

Figure 8a shows the accumulation of a low amount of carboxylic acids generated during the EOx process alone $(\bullet)$ and while testing the simultaneous $\mathrm{EOx} /[\mathrm{Fe}(\mathrm{VI})]$ processes using $12 \mathrm{mM}$ of $\mathrm{Fe}_{2} \mathrm{O}_{4}(\bullet)$ at $30 \mathrm{~mA} \mathrm{~cm}^{-2}$. The carboxylic acid quantified from BBR degradation was oxalic acid. Figure $8 \mathrm{~b}$ shows that oxalic acid generation contributed only almost $20 \mathrm{mg} / \mathrm{L}$ using the EOx process alone, whereas adding $12 \mathrm{mM}$ of $\mathrm{FeSO}_{4}$ produced only $2 \mathrm{mg} \mathrm{L}^{-1}$ under the simultaneous EOx/[Fe(VI)] process. These results suggest that the degradative pathway of BBR produces carboxylic acid because of the combined action of $\cdot \mathrm{OH}$ and ferrate ions generated in the solution [45-49]. 

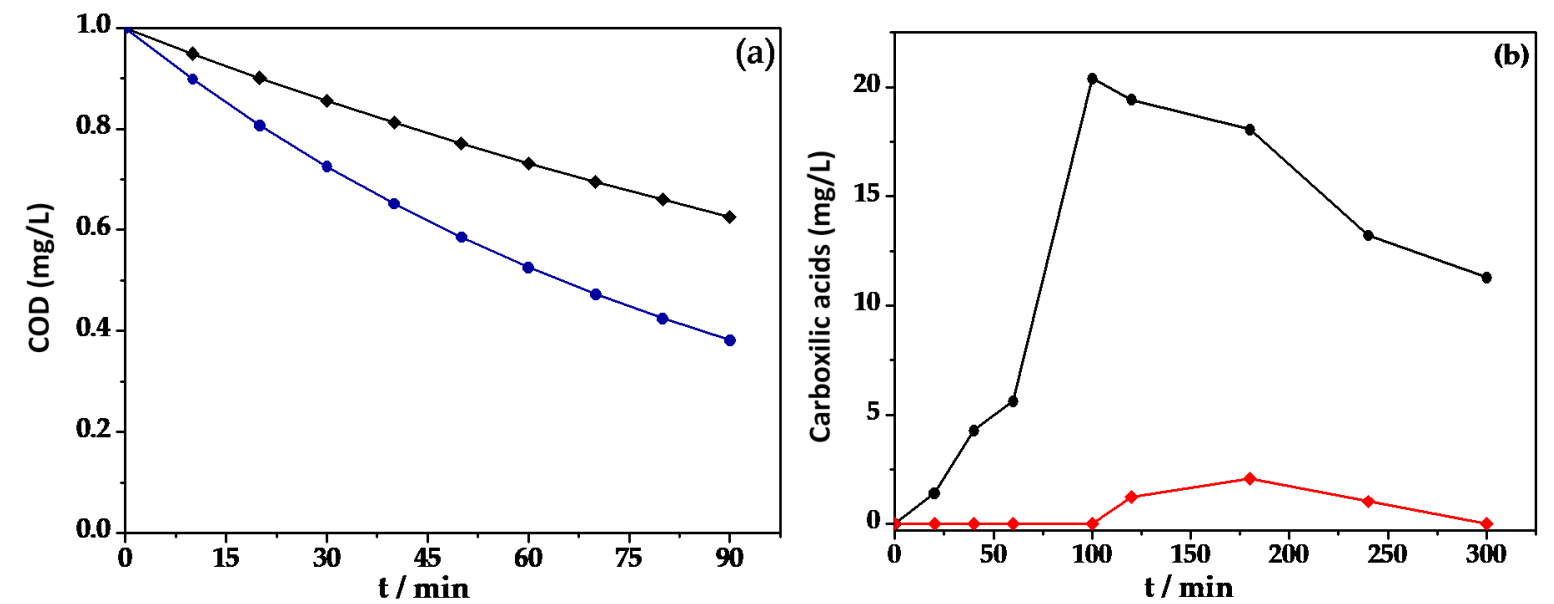

Figure 8. (a) Variation of COD abatement for $50 \mathrm{mg} / \mathrm{L}$ of BBR azo dye using BDD electrolysis without $\mathrm{FeSO}_{4}(\bullet)$ and the simultaneous EOx/[Fe(VI)] process using $12 \mathrm{mM}$ of $\mathrm{FeSO}_{4}(\bullet)$ in $0.05 \mathrm{M}$ of $\mathrm{Na}_{2} \mathrm{SO}_{4}$ at a $\mathrm{pH}$ of 3 at $30 \mathrm{~mA} \mathrm{~cm}^{-2}$. (b) Evolution of the concentration of oxalic acid produced during the degradation of $0.4 \mathrm{~L}$ of $50 \mathrm{mg} / \mathrm{L} \mathrm{BBR}$ solution in $0.05 \mathrm{M}$ of $\mathrm{Na}_{2} \mathrm{SO}_{4}$ at a $\mathrm{pH}$ of 3 and $35^{\circ} \mathrm{C}$ using BDD without $\mathrm{FeSO}_{4}(\bullet)$ and the simultaneous $\mathrm{EOx} /[\mathrm{Fe}(\mathrm{VI})]$ process using $12 \mathrm{mM}$ of $\mathrm{FeSO}_{4}(\diamond)$ at $30 \mathrm{~mA} \mathrm{~cm}^{-2}$.

\section{Conclusions}

Electrochemical characterization using cyclic voltammetry confirms the in situ electrogeneration of ferrate ions on the BDD surface by adding $\mathrm{FeSO}_{4}$ in both the sulfate and perchloric acid media. The use of $\mathrm{HClO}_{4}$ produced discoloration efficiency close to $93 \%$ after 120 min of treatment when $12 \mathrm{mM}$ of $\mathrm{FeSO}_{4}$ was added. However, faster degradation rates were observed using the sulfate medium, which achieved up to $98 \%$ of color reduction in 60 min of treatment when $12 \mathrm{mM}$ of $\mathrm{FeSO}_{4}$ was added and a current density of $30 \mathrm{~mA} \mathrm{~cm}^{-2}$ was applied. A COD abatement as high as $63 \%$ was observed when the highest $\mathrm{FeSO}_{4}$ concentration was added to the reaction mixture using the highest current density value. The byproduct analysis detected the presence of only one carboxylic acid (oxalic acid), which was rapidly oxidized by the simultaneous EOx/[Fe(VI)] process. These were identified as the best treatment conditions because they allowed some smaller amount reaction byproducts to accumulate.

Based on the obtained results, it was possible to demonstrate the viability of the simultaneous generation of both oxidant species, the free radical and the ferrate ion, which opens up an important opportunity to carry out not only the degradation of dyes, but also other organic compounds that are difficult to remove. This work provides an advance in the study of the simultaneous generation of oxidant species to the scientific community interested in this subject. In the future, the challenge will be understanding the reaction mechanisms.

Author Contributions: Conceptualization, P.J.E.-M. and J.M.P.-H.; methodology, P.J.E.-M. and J.M.P.-H.; validation, M.C.; formal analysis.; investigation, M.C., P.J.E.-M. and J.M.P.-H.; resources.; data curation, M.C. and P.J.E.-M.; writing-original draft preparation, M.C. and P.J.E.-M.; writing-review and editing, P.J.E.-M. and J.M.P.-H.; visualization.; supervision, J.M.P.-H.; project administration, J.M.P.-H.; funding acquisition J.M.P.-H., O.R., A.P., E.R.B. and S.G.-G. All authors have read and agreed to the published version of the manuscript.

Funding: The authors would like to acknowledge the economic support of the Universidad de Guanajuato.

Acknowledgments: O.M. Rodriguez-Narvaez and Alain Picos would like to thank CONACYT for a graduate fellowship. The authors are also grateful to Nicole Damon (DRI) for her editorial review.

Conflicts of Interest: The authors declare no conflict of interest.

\section{References}

1. Alcocer, S.; Picos, A.; Uribe, A.R.; Pérez, T.; Peralta-Hernández, J.M. Comparative study for degradation of industrial dyes by electrochemical advanced oxidation processes with BDD anode in a laboratory stirred tank reactor. Chemosphere 2018, 205, 682-689. [CrossRef] 
2. Alsheyab, M.; Jiang, J.-Q.; Stanford, C. On-line production of ferrate with an electrochemical method and its potential application for wastewater treatment-A review. J. Environ. Manag. 2009, 90, 1350-1356. [CrossRef]

3. Ambauen, N.; Muff, J.; Mai, N.L.; Hallé, C.; Trinh, T.T.; Meyn, T. Insights into the kinetics of intermediate formation during electrochemical oxidation of the organic model pollutant salicylic acid in chloride electrolyte. Water 2019, 11, 1322. [CrossRef]

4. Bennett, J.A.; Wang, J.; Show, Y.; Swain, G.M. Effect of sp2-Bonded Nondiamond Carbon Impurity on the Response of Boron-Doped Polycrystalline Diamond Thin-Film Electrodes. J. Electrochem. Soc. 2004, 151 , E306. [CrossRef]

5. Cataldo-Hernández, M.A.; Govindarajan, R.; Bonakdarpour, A.; Mohseni, M.; Wilkinson, D.P. Electrosynthesis of ferrate in a batch reactor at neutral conditions for drinking water applications. Can. J. Chem. Eng. 2018, 96, 1648-1655. [CrossRef]

6. Cataldo-Hernández, M.; Stewart, M.; Bonakdarpour, A.; Mohseni, M.; Wilkinson, D.P. Degradation of ferrate species produced electrochemically for use in drinking water treatment applications. Can. J. Chem. Eng. 2018, 96, 1045-1052. [CrossRef]

7. Cerreta, G.; Roccamante, M.A.; Oller, I.; Malato, S.; Rizzo, L. Contaminants of emerging concern removal from real wastewater by UV/free chlorine process: A comparison with solar/free chlorine and UV/H2O2 at pilot scale. Chemosphere 2019, 236, 124354. [CrossRef] [PubMed]

8. Cho, M.; Lee, Y.; Choi, W.; Chung, H.; Yoon, J. Study on Fe (VI) species as a disinfectant: Quantitative evaluation and modeling for inactivating Escherichia coli. Water Res. 2006, 40, 3580-3586. [CrossRef]

9. Coria, G.; Pérez, T.; Sirés, I.; Brillas, E.; Nava, J.L. Abatement of the antibiotic levofloxacin in a solar photoelectro-Fenton flow plant: Modeling the dissolved organic carbon concentration-time relationship. Chemosphere 2018, 198, 174-181. [CrossRef]

10. Dávila, O.O.; Bergeron, L.L.; Gutiérrez, P.R.; Jiménez, M.M.D.; Sirés, I.; Brillas, E.; Roig Navarro, A.F.; Arandes, J.B.; Llopis, J.V.S. Electrochemical oxidation of dibenzothiophene compounds on BDD electrode in acetonitrile-water medium. J. Electroanal. Chem. 2019, 847, 113172. [CrossRef]

11. Deng, Y.; Jung, C.; Liang, Y.; Goodey, N.; Waite, T.D. Ferrate (VI) decomposition in water in the absence and presence of natural organic matter (NOM). Chem. Eng. J. 2018, 334, 2335-2342. [CrossRef]

12. Denvir, A.; Pletcher, D. Electrochemical generation of ferrate Part I: Dissolution of an iron wool bed anode. J. Appl. Electrochem. 1996, 26, 815-822. [CrossRef]

13. Diaz, M.; Cataldo, M.; Ledezma, P.; Keller, J.; Doederer, K. Unravelling the mechanisms controlling the electro-generation of ferrate using four iron salts in boron-doped diamond electrodes. J. Electroanal. Chem. 2019, 854, 113501. [CrossRef]

14. Dos Santos, A.B.; Cervantes, F.J.; van Lier, J.B. Review paper on current technologies for decolourisation of textile wastewaters: Perspectives for anaerobic biotechnology. Bioresour. Technol. 2007, 98, 2369-2385. [CrossRef] [PubMed]

15. Elgrishi, N.; Rountree, K.J.; McCarthy, B.D.; Rountree, E.S.; Eisenhart, T.T.; Dempsey, J.L. A Practical Beginner's Guide to Cyclic Voltammetry. J. Chem. Educ. 2018, 95, 197-206. [CrossRef]

16. Eng, Y.Y.; Sharma, V.K.; Ray, A.K. Ferrate(VI): Green chemistry oxidant for degradation of cationic surfactant. Chemosphere 2006, 63, 1785-1790. [CrossRef]

17. Espinoza-Montero, P.J.; Vasquez-Medrano, R.; Ibanez, J.G.; Frontana-Uribe, B.A. Efficient anodic degradation of phenol paired to improved cathodic production of $\mathrm{H} 2 \mathrm{O} 2$ at BDD electrodes. J. Electrochem. Soc. 2013, 160, G3171-G3177. [CrossRef]

18. Espinoza, C.; Romero, J.; Villegas, L.; Cornejo-Ponce, L.; Salazar, R. Mineralization of the textile dye acid yellow 42 by solar photoelectro-Fenton in a lab-pilot plant. J. Hazard. Mater. 2016, 319, 24-33. [CrossRef]

19. Wood, R.H. The Heat, Free Energy and Entropy of the Ferrate(VI) Ion. J. Am. Chem. Soc. 2002, 80, $2038-2041$. [CrossRef]

20. Ibanez, J.G.; Tellez-Giron, M.; Alvarez, D.; Garcia-Pintor, E. Laboratory Experiments on the Electrochemical Remediation of the Environment. Part 6: Microscale Production of Ferrate. J. Chem. Educ. 2004, 81, 251. [CrossRef]

21. Jiang, J.-Q.; Lloyd, B. Progress in the development and use of ferrate(VI) salt as an oxidant and coagulant for water and wastewater treatment. Water Res. 2002, 36, 1397-1408. [CrossRef]

22. Jiang, J.Q. Advances in the development and application of ferrate(VI) for water and wastewater treatment. J. Chem. Technol. Biotechnol. 2014, 89, 165-177. [CrossRef] 
23. Kanari, N.; Ostrosi, E.; Diliberto, C.; Filippova, I.; Shallari, S.; Allain, E.; Diot, F.; Patisson, F.; Yvon, J. Green Process for Industrial Waste Transformation into Super-Oxidizing Materials Named Alkali Metal Ferrates (VI). Materials 2019, 12, 1977. [CrossRef] [PubMed]

24. Lee, J.; Tryk, D.A.; Fujishima, A.; Park, S.-M. Electrochemical generation of ferrate in acidic media at boron-doped diamond electrodes. Chem. Commun. 2002, 486-487. [CrossRef]

25. Lescuras-Darrou, V.; Lapicque, F.; Valentin, G. Electrochemical ferrate generation for waste water treatment using cast irons with high silicon contents. J. Appl. Electrochem. 2002, 32, 57-63. [CrossRef]

26. Liu, J.; Zhang, Z.; Liu, Z.; Zhang, X. Integration of ferrate (VI) pretreatment and ceramic membrane reactor for membrane fouling mitigation in reclaimed water treatment. J. Membr. Sci. 2018, 552, 315-325. [CrossRef]

27. Mácová, Z.; Bouzek, K.; Híveš, J.; Sharma, V.K.; Terryn, R.J.; Baum, J.C. Research progress in the electrochemical synthesis of ferrate(VI). Electrochim. Acta 2009, 54, 2673-2683. [CrossRef]

28. Martínez-huitle, C.A.; Brillas, E. Electrochemical Alternatives for Drinking Water Disinfection. Angew. Int. Ed. Chem. 2008, 47, 1998-2005. [CrossRef]

29. Morales, U.; Escudero, C.J.; Rivero, M.J.; Ortiz, I.; Rocha, J.M.; Peralta-Hernández, J.M. Coupling of the electrochemical oxidation (EO-BDD)/photocatalysis (TiO2-Fe-N) processes for degradation of acid blue BR dye. J. Electroanal. Chem. 2018, 808, 180-188. [CrossRef]

30. Oriol, R.; del Pilar Bernícola, M.; Brillas, E.; Cabot, P.L.; Sirés, I. Paired electro-oxidation of insecticide imidacloprid and electrodenitrification in simulated and real water matrices. Electrochim. Acta 2019, 317, 753-765. [CrossRef]

31. Pacheco-Álvarez, M.O.A.; Picos, A.; Pérez-Segura, T.; Peralta-Hernández, J.M. Proposal for highly efficient electrochemical discoloration and degradation of azo dyes with parallel arrangement electrodes. J. Electroanal. Chem. 2019, 838, 195-203. [CrossRef]

32. Panizza, M.; Cerisola, G. Application of diamond electrodes to electrochemical processes. Electrochim. Acta 2005, 51, 191-199. [CrossRef]

33. Villanueva-Rodríguez, M.; Hernández-Ramírez, A.; Peralta-Hernández, J.M.; Bandala, E.R.; Quiroz-Alfaro, M.A. Enhancing the electrochemical oxidation of acid-yellow 36 azo dye using boron-doped diamond electrodes by addition of ferrous ion. J. Hazard. Mater. 2009, 167, 1226-1230. [CrossRef] [PubMed]

34. Villanueva-Rodríguez, M.; Sánchez-Sánchez, C.M.; Montiel, V.; Brillas, E.; Peralta-Hernández, J.M.; Hernández-Ramírez, A. Characterization of ferrate ion electrogeneration in acidic media by voltammetry and scanning electrochemical microscopy. Assessment of its reactivity on 2, 4-dichlorophenoxyacetic acid degradation. Electrochim. Acta 2012, 64, 196-204.

35. Queiroz, N.M.P.; Sirés, I.; Zanta, C.L.P.S.; Tonholo, J.; Brillas, E. Removal of the drug procaine from acidic aqueous solutions using a flow reactor with a boron-doped diamond anode. Sep. Purif. Technol. 2019, 216, 65-73. [CrossRef]

36. Rice, E.W.; Baird, R.B.; Eaton, A.D.; Clesceri, L.S. Standard Methods for the Examination of Water and Wastewater; American Public Health Association: Washington, DC, USA, 2012; p. 541.

37. Ruiz, E.J.; Hernández-Ramírez, A.; Peralta-Hernández, J.M.; Arias, C.; Brillas, E. Application of solar photoelectro-Fenton technology to azo dyes mineralization: Effect of current density, $\mathrm{Fe} 2+$ and dye concentrations. Chem. Eng. J. 2011, 171, 385-392. [CrossRef]

38. Serrano, K.; Michaud, P.A.; Comninellis, C.; Savall, A. Electrochemical preparation of peroxodisulfuric acid using boron doped diamond thin film electrodes. Electrochim. Acta 2002, 48, 431-436. [CrossRef]

39. Sharma, V.K. Potassium ferrate(VI): Properties and applications. ACS Div. Environ. Chem. Prepr. 2000, 40, 131-132.

40. Sharma, V.K.; Burnett, C.R.; O'Connor, D.B. Ferrate(VI) and ferrate(V) oxidation of thiocyanate. ACS Div. Environ. Chem. Prepr. 2000, 40, 600-601.

41. Sharma, V.K. Potassium ferrate(VI): An environmentally friendly oxidant. Adv. Environ. Res. 2002, 6, 143-156. [CrossRef]

42. Sharma, V.K.; Kazama, F.; Jiangyong, H.; Ray, A.K. Ferrates (iron(VI) and iron(V)): Environmentally friendly oxidants and disinfectants. J. Water Health 2005, 3, 45-58. [CrossRef] [PubMed]

43. Sharma, V.K.; Rivera, W.; Joshi, V.N.; Millero, F.J.; O'Connor, D. Ferrate(VI) Oxidation of Thiourea. Environ. Sci. Technol. 1999, 33, 2645-2650. [CrossRef] 
44. Talaiekhozani, A.; Talaei, M.R.; Rezania, S. An overview on production and application of ferrate (VI) for chemical oxidation, coagulation and disinfection of water and wastewater. J. Environ. Chem. Eng. 2017, 5, 1828-1842. [CrossRef]

45. Thiam, A.; Salazar, R. Fenton-based electrochemical degradation of metolachlor in aqueous solution by means of BDD and Pt electrodes: Influencing factors and reaction pathways. Environ. Sci. Pollut. Res. 2019, 26, 2580-2591. [CrossRef]

46. Pérez, T.; Sirés, I.; Brillas, E.; Nava, J.L. Solar photoelectro-Fenton flow plant modeling for the degradation of the antibiotic erythromycin in sulfate medium. Electrochim. Acta 2017, 228, 45-56. [CrossRef]

47. Potts, M.E.; Churchwell, D.R. Removal of Radionuclides in Wastewaters Utilizing Potassium ferrate(VI). Water Environ. Res. 1994, 66, 107-109. [CrossRef]

48. Ye, Z.; Brillas, E.; Centellas, F.; Cabot, P.L.; Sirés, I. Electro-Fenton process at mild pH using Fe(III)-EDDS as soluble catalyst and carbon felt as cathode. Appl. Catal. B Environ. 2019, 257, 117907. [CrossRef]

49. Lee, Y.; Cho, M.K.; Kim, J.Y.; Yoon, J. Chemistry of Ferrate (Fe(VI)) in Aqueous Solution and its Applications as a Green Chemical. J. Ind. Eng. Chem. 2004, 10, 161-171.

(C) 2020 by the authors. Licensee MDPI, Basel, Switzerland. This article is an open access article distributed under the terms and conditions of the Creative Commons Attribution (CC BY) license (http://creativecommons.org/licenses/by/4.0/). 